\title{
Physico-chemical Properties Gelatin from Bone of Pangasius sutchi Extracted with Citrus Fruits
}

\author{
Yoni Atma 1,*iD, Moh. Taufik 1,2 (D) \\ 1 Department of Food Science and Technology, Faculty of Bioindustry, Universitas Trilogi, Jakarta, Indonesia \\ 2 Centre for Halal Research, IAIN Surakarta, Central Java, Indonesia \\ * Correspondence: yoniatma@trilogi.ac.id;
}

Scopus Author ID 57194092488

Received: 12.11.2020; Revised: 8.12.2020; Accepted: 9.12.2020; Published: 12.12.2020

\begin{abstract}
This research was extracted gelatin from the bones of Pangasius catfish without any chemical interventions. This research is expected to substitute unsafe chemicals and reduce fishery and agriculture waste with respect to sustainable, eco-friendly, and environmental concerns. This research was done by three steps, i.e., gelatin extraction (pre-treatment and main extraction), gelatin identification, and physicochemical analysis for the selected treatment. The pre-treatment used four types of Citrus fruits marked as Citrus A, B, C, and D for 24, 36, 48, and 56 hours. Then continued with the main extraction on the water at $45,55,65$, and $75^{\circ} \mathrm{C}$ for $5 \mathrm{~h}$. As a result, through Sodium Dodecyl Sulphate Polyacrylamide Gel Electrophoresis (SDS-PAGE) molecular weight identification, the gelatin was successfully extracted using Citrus C D. The fish gelatin contains 1.61-3.83 g/100 g protein and $0.67-1.69 \mathrm{~g} / 100 \mathrm{~g}$ hydroxyproline. The gelatin yield was $6.26 \%$, the gel strength of $451 \mathrm{~g}$, the hardness of $10.33 \mathrm{~N}$, the cohesiveness of 0.95 , springiness of $1.46 \mathrm{~mm}$, gumminess of $9.81 \mathrm{~N}$, and chewiness of $14.32 \mathrm{~N}$. Viscosity and $\mathrm{pH}$ of gelatin solution which obtained were $3.17 \mathrm{cP}$ and 4.42 respectively. The proximate characteristics are moisture $8.81 \%$, ash $1.12 \%$, crude protein $58.47 \%$, and fat $4.13 \%$.
\end{abstract}

Keywords: fish gelatin; by-products; green extraction; Pangasius sutchi; profile texture.

(c) 2020 by the authors. This article is an open-access article distributed under the terms and conditions of the Creative Commons Attribution (CC BY) license (https://creativecommons.org/licenses/by/4.0/).

\section{Introduction}

Gelatin is a type of protein derived from collagen extracted from skin and bones [1, 2, $3,4,5]$. The market share of gelatin is $90 \%$ of mammalian [6]. The most potential as alternative sources of gelatin is skin and bone of fish [7,8]. The scientists explain that gelatin from fish can be alternative gelatin $[9,10]$ and has bioactive properties, i.e., antioxidant and antihypertensive $[11,12]$. Fish's skin is usually still used and sometimes undeliberately attached to fish meat for consumption and further processing, while the fish bones are often disposed of. The utilization of fish bones as a gelatin source can reduce waste and provide value-added for useless marine products. Also, gelatin produced from the by-product of warmwater fish has better thermostability, gel strength, viscosity, and rheology properties compared to cold-water fish [13]. One of the highest extractions yields of fish-based gelatin comes from Pangasius catfish (Pangasius sutchi) as reported by Mahmoodani et al. (2014) that used a combination of acidic solvent and water. Gelatin from Pangasius catfish bones also has physical characteristics similar to traditional gelatin [14].

The extraction of fish gelatin has two steps; pre-treatment and main extraction. The acidic solvent is mostly recommended and adopted in pre-treatment of fishbone gelatin extraction. Previous studies showed that using hydrogen chloride during pre-treatment gave 
higher gelatin yields than sodium hydroxide, sulfuric acid, and other solvents [15]. On the other hand, some researches have been tried providing mild acidic solvent such as citric acid for the pre-treatment. This approach is believed to be a promising method to support green and sustainable extraction since the main extraction usually uses water. One of the principles of green extraction is the use of alternative solvents and principally water or agro-solvents [16]. Even citric acid is categorized as a green and naturally biodegradable catalyst [17]. Although this leads to long time extraction, however, basically, the gelatin has been recovered, and the solvent is safe and environmentally friendly. Maroid and Adam (2013) stated that pre-treatment could be better and potential if using citric acid [18]. Citric acid is known as a low acute chemical. Nevertheless, it will also have a challenge concerning the threshold tolerance issue. No Observed Adverse Effect Level (NOAEL) of citric acid is $1200 \mathrm{mg} / \mathrm{kg} / \mathrm{d}$ [19].

Therefore, in this research, we extracted gelatin from the bone of Pangasius sutchi without chemicals by replacing the citric acid solvent with citrus fruit extracts. Citric acid is naturally most concentrated in citrus fruits such as lemon $( \pm 48 \mathrm{~g} / \mathrm{L})$, lime $( \pm 45.8 \mathrm{~g} / \mathrm{L})$ [20], grapefruits $(64.7 \mathrm{mmol} / \mathrm{L})$, orange $(47.36 \mathrm{mmol} / \mathrm{L})$ [21]. This research expected to substitute chemicals for gelatin extraction technology and minimize fishery and agriculture waste heading to environment protection, organic, and back to nature campaigns. Furthermore, because of indicators, gelatin extraction is gelatin existence, extraction yield, physical, and chemical characteristics of obtained gelatin. The gelatin identification, yield, profile texture, and proximate composition the fish gelatin also performed. It is also to compare with previous researches and with the standard of mammalian gelatin.

\section{Materials and Methods}

\subsection{Gelatin extraction.}

The bone of Pangasius sutchi was separated from other wastes such as head, fin, scale, and viscera. The bones were scraped with a knife and tumbled in warm water $\left(80-90{ }^{\circ} \mathrm{C}\right)$ for 30 minutes to easily remove the attached flesh. Then, fish bones were washed using tap water and stored in the freezer $\left(-20^{\circ} \mathrm{C}\right)$ for a month. The Citrus fruits were peeled, extracted, filtered, and then stored at $4^{\circ} \mathrm{C}$ before the pre-treatment. The gelatin extraction was carried out by two steps, i.e., pre-treatment and main extraction $[14,18]$. In the pre-treatment step, cleaned bones were minced in a meat grinder and then soaked into four types of Citrus fruit extracts marked as Citrus A, B, C, and D with bone: solvent ratio 1:5 (w/v). Pre-treatment was carried out at room temperature with varying periods $(24,36,48,56$ hours) to demineralization. Then, the leached bone (ossein) obtained separated with the Citrus fruits (pre-treatment solvent) by centrifugation for $10 \mathrm{~min}$ at $10.000 \mathrm{xg} 4{ }^{\circ} \mathrm{C}$. The ossein neutralized by washing under distilled water until it reached $\mathrm{pH}$ 7. Then, the neutralized ossein soaked into the water at a ratio of 1:5 (ossein/water, (w/v)) for the main extraction stage. The main extraction was carried out for $5 \mathrm{~h}$ at different temperatures $\left(45,55,65,75^{\circ} \mathrm{C}\right)$. Finally, the extracted gelatin is filtered using filter paper and stored at $4{ }^{\circ} \mathrm{C}$ before further analysis.

\subsection{Gelatin identification.}

Gelatin identification carried out in three approaches, namely sodium dodecyl sulphate polyacrylamide gel electrophoresis (SDS-PAGE) for qualitatively analysis, bicinchoninic acid (BCA) and hydroxyproline assays both as quantitatively analysis. The SDS-PAGE was 
performed through a discontinues Tris/HCl/glycine buffer system $[14,22]$ in order to find bands in the molecular weight (MW) $97-140 \mathrm{kDa}$, which means the gelatin is successfully extracted. Then, the BCA analysis was adopted from Atma and Hisworo (2017) carried out quantify protein concentration on extracted gelatin solution [15], whilst the hydroxyproline quantification was performed to measure the hydroxyproline concentration on gelatin solution [23]. The hydroxyproline is one of the dominant amino acids in the gelatin structure. The hydroxyproline content was analyzed using $a$ hydroxyproline assay kit (Biovision Inc. Milpitas, CA, USA) as mentioned by our previous work [24].

\subsection{Gelatin yield.}

The gelatin yield was calculated as the ratio of the weight of dried gelatin to the total weight of fish ossein on a wet basis using the formula described by Mahmoodhani et al. (2014) as following [14]:

$$
\text { Yield }(\%)=(\text { Dry weight gelatin }(\mathrm{g}) / \text { Wet weight of } \text { ossein }(\mathrm{g})) \times 100
$$

\subsection{Gel strength and profile texture.}

Ayudiarti et al. (2020) explained that gel strength is the force needed by the probe to press the gel as high as $4 \mathrm{~mm}$ until the gel breaks [25]. The gel strength was determined on crude extract gelatin with the method of analysis based on Taheri et al. (2009) with few modifications in terms of gelatin concentration and type of probe [26] and Atma et al. (2018) [27] with slight modification only on gelatin concentration. First, the gelatin was heated at $60^{\circ} \mathrm{C}$ and stirred for 15 min by a hot plate magnetic stirrer (Stuart, UK). Then the liquid and homogenized gelatin poured into the bloom jar. Second, the gelatin was incubated in a refrigerator for 16-18 $\mathrm{h}$ for maturation. The gel strength measured using Texture Analyzer CT3 (Brookfield, US) with a load cell of $\pm 5 \mathrm{~kg}$, crosshead speed of $1 \mathrm{~mm} / \mathrm{s}$, and a diameter of 5 $\mathrm{mm}$. The maximum force on grams bloom was determined when the plugger penetrated $4 \mathrm{~mm}$ into gelatin gel through the bloom jar's center (apoetema). While the texture profile analysis (TPA) was prepared the same as gel strength determination, it was just additional treatment by equilibrate the gel at $15{ }^{\circ} \mathrm{C}$ for 15 minutes after maturation. The textural parameters were measured by using Texture Analyzer CT3 equipped with an aluminum probe. The probe compressed the gel with a speed of $1.0 \mathrm{~mm} / \mathrm{s}$, then the parameters measured when deformation reached $25 \%[14,28]$.

\subsection{Viscosity and $p H$.}

The viscosity was measured on crude extract gelatin using the Brookfield Digital Viscometer (LV Brookfield, UK) equipped with a spindle SC4-31. The viscosity in $\mathrm{cP}$ was determined within $60 \mathrm{rpm}$ in spindle speed at room temperature $\left(27^{\circ} \mathrm{C}\right)$ as described by Jeya Shakila et al. (2012) [23]. Then for the $\mathrm{pH}$, the gelatin was homogenized at $60^{\circ} \mathrm{C}, 3 \mathrm{rpm}$ for 30 minutes. Liquid gelatin cooled at ambient temperature for a while. Afterward, the gelatin solution's $\mathrm{pH}$ was measured with a glass electrode $\mathrm{pH}$ meter (Agilent, USA), which had

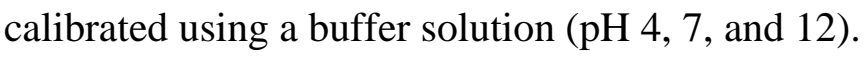

\subsection{Proximate analysis.}

The moisture (oven-drying procedure), crude protein (Kjeldahl method), ash, and fat content (Soxhlet extraction) of fishbone gelatin was estimated by the AOAC official method 
[29]. The crude protein was quantified using the nitrogen-to-protein conversion factor; it was set at 5.4.

\section{Results and Discussion}

\subsection{Gelatin extraction and identification.}

Modification of the extraction parameters have changes the yields [30]. Thus, the reason for choosing pre-treatment times and main extraction temperatures in this research was based on a study conducted by Mahmoodani et al. (2014), which concluded that the optimal condition for extraction gelatin from the bone of Pangsius sutchi was pre-treatment of 21.15 hours, extraction temperature of $74.73^{\circ} \mathrm{C}$, and main extraction time of 5.26 hours. This research was using hydrogen chloride $(\mathrm{HCl})$ during the pre-treatment stage and the data analyzed by the response surface methodology (RSM) approach. Accordingly, the extraction using mild and soft acidic solvents should be longer. Therefore, in this study, the pre-treatment time was arranged on 24 until $56 \mathrm{~h}$, and the main extraction of $5 \mathrm{~h}$ at 45 to $75^{\circ} \mathrm{C}$. It could be asked to set the temperature above $75^{\circ} \mathrm{C}$, yet it is commonly believed that protein degradation would be dominant. Moreover, concerning methods for gelatin identification, most of the research on fish-based gelatin extraction was confirmed the existence of gelatin on an extracted solution or dried extraction by using sodium dodecyl sulfate-polyacrylamide gel electrophoresis (SDSPAGE) $[14,23,26]$ since this technique appears the band of specific protein such as gelatin. Previous studies also analyzed the hydroxyproline content on extracted gelatin in which this amino acid is unique and acts as one of the predominant amino acids found on gelatin. The proportion of imino acid (prolin+hydroxyproline) has a pivotal role in gelatin's gelling capability [28]. Thus, the SDS-PAGE, protein content, and hydroxyproline concentration are also essential analyses in this research, which represent in Figures 1-4 and table 1.

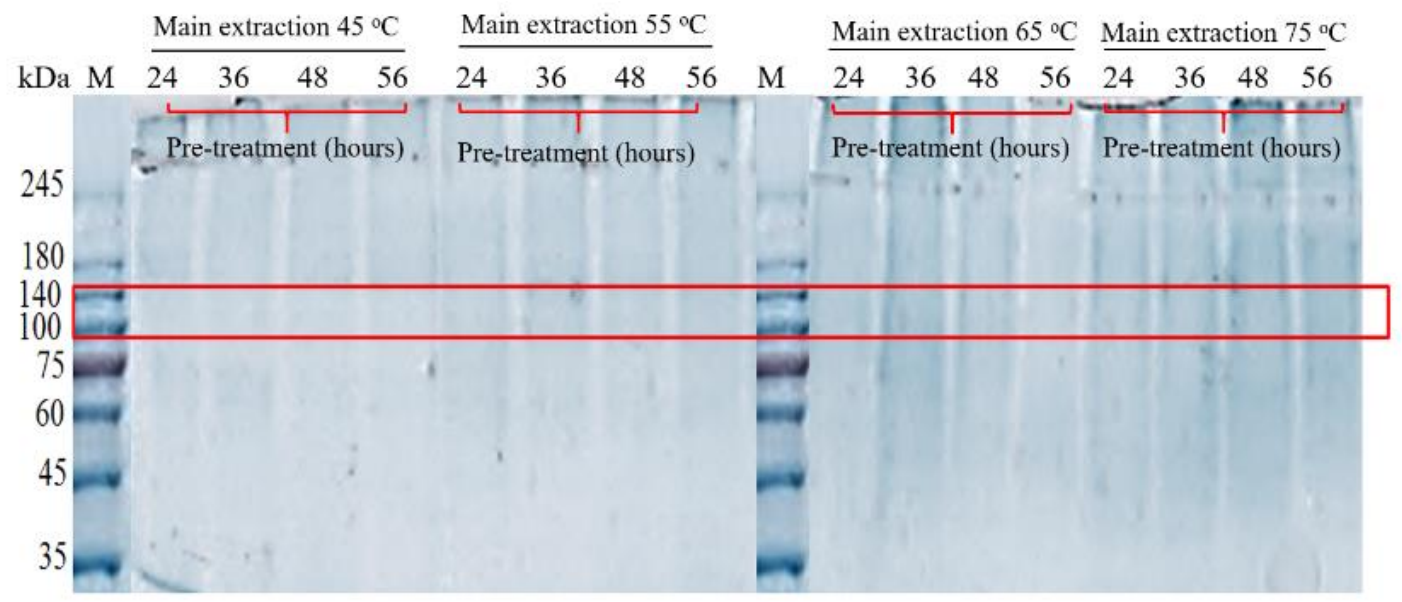

Figure 1. SDS-PAGE of filtered liquid from the bone of Pangsius sutchi extracted with Citrus fruit A for different pre-treatment times $(24-56 \mathrm{~h})$ dan main extraction temperatures $\left(45-75^{\circ} \mathrm{C}\right), \mathrm{M}=$ marker protein with a range of molecular weights $(35-245 \mathrm{kDa})$. 


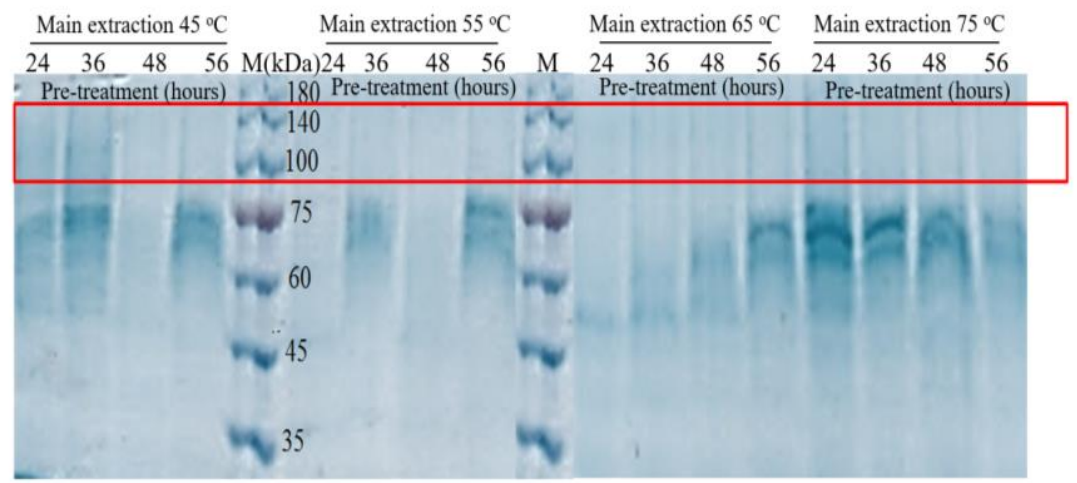

Figure 2. SDS-PAGE of filtered liquid from the bone of Pangsius sutchi extracted with Citrus fruit B for different pre-treatment times $(24-56 \mathrm{~h})$ dan main extraction temperatures $\left(45-75^{\circ} \mathrm{C}\right), \mathrm{M}=$ marker protein with a range of molecular weights $(35-245 \mathrm{kDa})$.

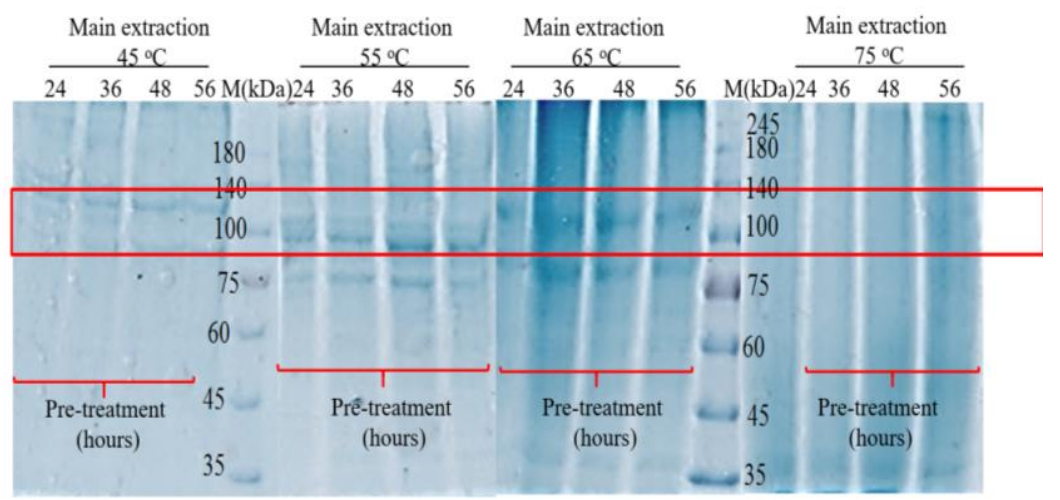

Figure 3. SDS-PAGE of filtered liquid from the bone of Pangsius sutchi extracted with Citrus fruit $\mathrm{C}$ for different pre-treatment times $(24-56 \mathrm{~h})$ dan main extraction temperatures $\left(45-75^{\circ} \mathrm{C}\right), \mathrm{M}=$ marker protein with a range of molecular weights $(35-245 \mathrm{kDa})$.

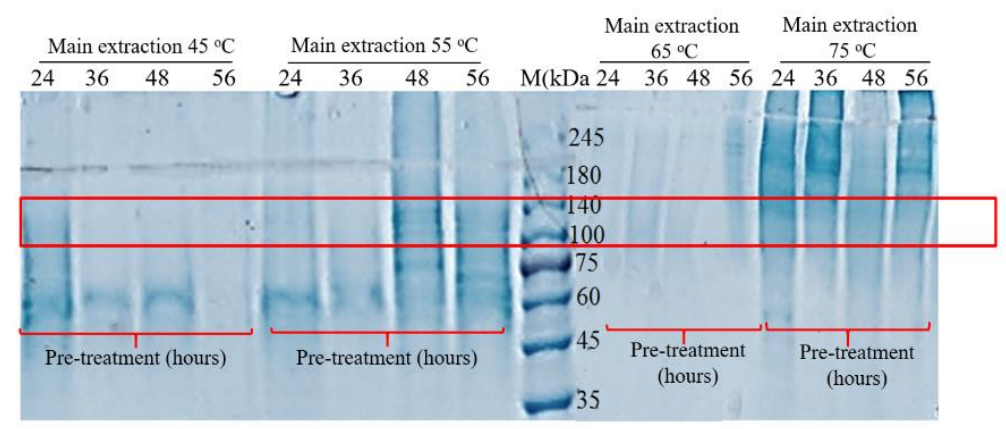

Figure 4. SDS-PAGE of filtered liquid from the bone of Pangsius sutchi extracted with Citrus fruit D for different pre-treatment times $(24-56 \mathrm{~h})$ dan main extraction temperatures $\left(45-75^{\circ} \mathrm{C}\right), \mathrm{M}=$ marker protein with a range of molecular weights $(35-245 \mathrm{kDa})$.

Table 1. The average protein concentration and hydroxyproline content of fishbone gelatin extracted with Citrus fruits.

\begin{tabular}{l|c|c|c|c}
\multirow{2}{*}{ Citrus fruit } & \multicolumn{2}{|c|}{ Extraction Condition } & Protein Concentration & Hydroxyproline \\
\cline { 2 - 4 } & $\begin{array}{c}\text { Pre-treatment } \\
\text { time }\end{array}$ & $\begin{array}{c}\text { Main Extraction } \\
\text { temperature }\end{array}$ & $\begin{array}{c}\text { content }(\mathbf{g} / \mathbf{1 0 0 g}) \\
\text { cont }\end{array}$ \\
\hline $\mathrm{C}$ & 48 hours & $55^{\circ} \mathrm{C}$ & 3.83 & 1.69 \\
\hline $\mathrm{D}$ & 48 hours & $55^{\circ} \mathrm{C}$ & 1.61 & 0.67
\end{tabular}

Previous studies were found that gelatin from the bone of Pangasius sutchi has a molecular weight (MW) around 97-140 kDa [14, 15, 27]. Figures 1-4 has shown the SDSPAGE of extracted solution from the bone of Pangsius sutchi with different extraction treatments with respect to gelatin recovery. Although there is an absence of gelatin on 
extraction using citrus fruit A and B shown by none of the band found in their electroforegram, fortunately, based on figures 3 and 4, the gelatin successfully extracted using citrus fruit $\mathrm{C}$ and $\mathrm{D}$ for particular pre-treatment and main extraction conditions. Actually, some bands are still found on SDS-PAGE of citrus fruit B; however, the bands appear on the MW below 97-140 $\mathrm{kDa}$. The protein or gelatin could be there; theoretically, they might be hydrolyzed during the extraction period creating smaller MW $(\leq 75 \mathrm{kDa})$ [31]. While for the extraction using citrus $\mathrm{C}$, the bands have been noticed in all pre-treatment times and main extraction below $75^{\circ} \mathrm{C}$, and for the extraction using citrus $\mathrm{D}$, the bands found in the pre-treatment for $48 \mathrm{~h}, 56 \mathrm{~h}$ at main extraction $55^{\circ} \mathrm{C}$. The SDS-PAGE of gelatin extraction using citrus D also shows some higher MW bands like present on pre-treatment combined the main extraction at $75{ }^{\circ} \mathrm{C}$ and lowered MW such present on pre-treatment combined main extraction $45^{\circ} \mathrm{C}$. Wisely, with respect to previous studies about MW of fishbone gelatin [14, 15, 27], the electroforegram, which presents intense bands at MW $97-140 \mathrm{kDa}$, is chosen for further conformations. Also, the selection of extraction treatment is also based on shorter pre-treatment time and lower main extraction temperature. It concerns gelatin stability during extraction would be better than longer pre-treatment times and higher main extraction temperatures. Hence, the pre-treatment using citrus $\mathrm{C}$ and $\mathrm{D}$ for $48 \mathrm{~h}$ and the main extraction at $55{ }^{\circ} \mathrm{C}$ were decided as selected treatments. Table 1 presents the protein and hydroxyproline concentrations of each selected treatment.

Table 2. The average yield of gelatin from the bone of Pangsius sutchi extracted with Citrus fruit $\mathrm{C}$ compared to other studies.

\begin{tabular}{|c|c|c|c|c|}
\hline \multirow{2}{*}{$\begin{array}{l}\text { Sources of fish bone } \\
\text { gelatin (species) }\end{array}$} & \multicolumn{2}{|c|}{ Extraction Condition } & \multirow{2}{*}{ Yield (\%) } & \multirow{2}{*}{ References } \\
\hline & Pre-treatment & Main Extraction & & \\
\hline \multirow{3}{*}{ Pangasius sutchi } & Citrus fruit, $48 \mathrm{~h}$ & Water, $55^{\circ} \mathrm{C}, 5 \mathrm{~h}$ & 6.26 & This study \\
\hline & Pineapple peels, $56 \mathrm{~h}$ & Water, $75^{\circ} \mathrm{C}, 5 \mathrm{~h}$ & 6.12 & {$[27]$} \\
\hline & Citric acid, $48 \mathrm{~h}$ & Water, $75^{\circ} \mathrm{C}, 5 \mathrm{~h}$ & 6.14 & {$[32]$} \\
\hline Saurida tumbil & $\begin{array}{l}\text { Sodium hydroxyde } 40 \mathrm{~min} \text {, } \\
+ \text { sulfuric acid } 40 \mathrm{~min} \text {, and } \\
\text { citric acid } 40 \mathrm{~min}\end{array}$ & $\begin{array}{c}\text { Water, } 40-50^{\circ} \mathrm{C}, \\
12 \mathrm{~h}\end{array}$ & 5.08 & [26] \\
\hline Otolithes ruber & \multirow{2}{*}{$\begin{array}{l}\text { Sodium hydroxyde } 40 \mathrm{~min} \text {, } \\
+ \text { sulfuric acid } 40 \mathrm{~min} \text {, and } \\
\text { citric acid } 40 \mathrm{~min}\end{array}$} & \multirow[b]{2}{*}{ Water, $45^{\circ} \mathrm{C}, 12 \mathrm{~h}$} & 4.57 & [33] \\
\hline Nemipterus japonicus & & & 3.55 & {$[33]$} \\
\hline
\end{tabular}

Table 2 shows the yield of gelatin by extraction using citrus fruit $\mathrm{C}$ in the pre-treatment of $48 \mathrm{~h}$ and the main extraction $55^{\circ} \mathrm{C}$ for $5 \mathrm{~h}$ compared to other studies. This treatment is chosen because it provides higher protein and hydroxyproline content than citrus fruit $\mathrm{D}$ (Table 1). Table 2 proved that citrus fruit could be used as a solvent for gelatin extraction replacing citric acid, sodium hydroxide, and sulfuric acid. The yield represents the quantity of gelatin in a powder or dried form obtained from raw material (bones). This parameter is necessary for the industrial scale. Indeed, this study's yield was lower than gelatin from the bone of Pangasius sutchi published by Mahmoodani et al. (2014), who had obtained a yield of around $13.86 \%$ [14]. However, our study did not employ chemicals during extraction and has not optimized the extraction process yet.

\subsection{Physical properties of fishbone gelatin.}

The gelatin has two important physical properties; gel strength and a viscosity [34]. These parameters are correlated with gelatin as additive and biomaterial in food, pharmaceutical, cosmetics. The mammalian based gelatin has great physical characteristics compared to fish-based gelatin [35]. Consequently, most research on fish gelatin extraction 
carried out the analysis for gel strength and viscosity concerning standard mammalian gelatin. The gelatin's gel strength and viscosity in this work, other research, and mammalian gelatin are presented in Table 3. Though, the method for determination of gel strength of fish gelatin in this research was slightly different from the method analyzing gel strength of gelatin described by Gelatin Manufacture of America (GMIA) or Gelatin Manufacture of Europe (GME) which the gelatin concentration should be $6.67 \%$ [36, 37]. At the same time, this research measured the gel strength and viscosity of fishbone gelatin solution directly after extraction without prior drying and desolvation.

Nevertheless, another study, which had measured the gel strength of fishbone gelatin extracted with pineapple waste, provided the gel strength value of 430 g.bloom for the crude solution and 64.83 g.bloom for the $6.67 \%$ gelatin solution [27]. The standard of gel strength for gelatin is 50-300 g.bloom [36], which means that the fish gelatin extracted with citrus fruit should be confirmed with the standard. Besides, there are many techniques to improve the gel strength of fish gelatin that could be adopted in the future.

Mahmoodani et al. (2014) found that the gel strength of fishbone gelatin extracted from Pangasius sutchi with hydrochloric acid was 254.7 g.bloom [14]. The gel strength cannot fully represent the texture behavior of gelatin. Many types of research on fish gelatin extraction also had determined the texture profile of which covering hardness, cohesiveness, springiness, gumminess, and chewiness. This study measured the texture profile of fishbone gelatin solution. Likewise, gel strength analysis, the texture profile measurement also performed on gelatin solution without concentration dilution to $6.67 \%$. The profile texture of fishbone gelatin from Pangasius sutchi extracted with citrus fruit is represented on Tabel 3. Various factors affect the physical and mechanical properties of gelatin, which have already been stated, including amino acid composition, imino acid (Pro+Hyp) proportion [28], extraction method, and molecular weight (MW) distribution [38].

Table 3. The average physical properties of gelatin from the bone of Pangsius sutchi extracted with Citrus fruit compared with pineapple waste and mammalian gelatin.

\begin{tabular}{|c|c|c|c|}
\hline \multirow{2}{*}{ Physical properties } & \multicolumn{2}{|c|}{ Green-based Extraction Solvent } & \multirow{2}{*}{$\begin{array}{l}\text { Mammalian gelatin } \\
(6.67 \% \text { gelatin) [39] }\end{array}$} \\
\hline & Citrus fruit and water & Pineapple waste and water ${ }^{*}$ & \\
\hline Gel Strength (g.bloom) & 451 & 430 & 466 \\
\hline \multicolumn{4}{|l|}{ Texture Profile } \\
\hline Hardness $(N)$ & 10.33 & 9.83 & 14.40 \\
\hline Cohesiveness & 0.95 & 0.46 & 0.91 \\
\hline Springiness $(\mathrm{mm})$ & 1.46 & 2.91 & 0.94 \\
\hline Gumminess $(N)$ & 9.81 & 4.52 & 13.17 \\
\hline Chewiness $(N)$ & 14.32 & 13.15 & 12.45 \\
\hline Viscosity $(\mathrm{cP})$ & 3.17 & 3.17 & 3.90 \\
\hline $\mathrm{pH}$ & 4.42 & 4.52 & 6.18 \\
\hline
\end{tabular}

\subsection{Chemical properties of fishbone gelatin.}

The proximate composition of fish gelatin extracted from the bone of Pangasius sutchi in this research, along with other pre-treatment approaches (pineapple waste and citric acid) and the mammalian gelatin, are presented in Table 4. Proximate analysis in our research was similar to other research in terms of an analysis method. There are three chemical compositions on gelatin that must be highlighted, covering moisture, ash, and protein content. The moisture content of gelatin, which international standardization is issued, requires a maximum of $16 \%$, and ash content should be below 3.3\% [36]. It is suggested that the gelatin from the bone of Pangasius sutchi, which is extracted with citrus fruit, has moisture and ash contents confirmed with the standard. In addition, there are no standard requirements for crude protein percentage 
of gelatin; however, gelatin is a protein, so that higher protein content is extremely desirable. The protein content of fish gelatin from similar bone species, which demineralized using hydrochloric acid $(\mathrm{HCl})$, was $87.3 \%$ [14]. The protein content in this study lower than the previous one might be caused by solvent for pre-treatment in this research is a citrus fruit which has mild and low acidity compared to $\mathrm{HCl}$. The pre-treatment stage in extraction gelatin is crucial due to demineralization occurring to release the bones' protein [40]. Furthermore, there is less attention toward this composition regarding fat content, and mostly just quantified accompaniment with proximate analysis. Nevertheless, the opposite result with protein expectancy was desired, which means that a lower fat percentage improves gelatin's chemical quality [41].

Table 4. The average proximate composition of gelatin from the bone of Pangsius sutchi extracted with Citrus

\begin{tabular}{|c|c|c|c|c|}
\hline \multirow[b]{2}{*}{$\begin{array}{l}\text { Proximate } \\
\text { Composition }\end{array}$} & \multicolumn{3}{|c|}{$\begin{array}{l}\text { fruit compared with other studies } \\
\text { Green-based Extraction Solvent }\end{array}$} & \multirow[b]{2}{*}{$\begin{array}{c}\text { Mammalian gelatin } \\
{[39]}\end{array}$} \\
\hline & $\begin{array}{l}\text { Citrus fruit } \\
\text { and water }\end{array}$ & $\begin{array}{l}\text { Pineapple waste } \\
\text { and water [27] }\end{array}$ & $\begin{array}{l}\text { Citric acid and } \\
\text { water [32] }\end{array}$ & \\
\hline Moisture (\%) & 8.81 & 8.59 & 7.72 & 9.56 \\
\hline $\operatorname{Ash}(\%)$ & 1.12 & 0.95 & 0.38 & 0.1 \\
\hline Crude Protein (\%) & 58.47 & 47.60 & 58.70 & 90 \\
\hline Fat (\%) & 4.13 & 7.71 & 2.79 & - \\
\hline
\end{tabular}

\section{Conclusions}

Gelatin successfully extracted from the bone of Pangasius sutchi using citric acid at the pre-treatment for $48 \mathrm{~h}$ and main extraction using water for $5 \mathrm{~h}$ at $55^{\circ} \mathrm{C}$. The physico-chemical properties of this gelatin in the form of a crude solution are confirmed with standard gelatin. However, the crude protein percentage is still lower than mammalian gelatin and gelatin, extracted using chemicals. This study offers an alternative and agro-solvent for gelatin extraction concerning safety, sustainability, environmental, and natural concerns.

\section{Funding}

This research received no external funding.

\section{Acknowledgments}

We would like to thank the Toray Science Foundation, which represented by Indonesian Toray Science Foundation (ITSF), for the research grant.

\section{Conflicts of Interest}

The authors declare no conflict of interest.

\section{References}

1. Jamaluddin; Khumaidi, A.; Entending, H.; Yuyun, Y.; Widodo, A.; Pitriani. Quality determination and gelatin identification bone of eel fish (anguilla marmorata (q) gaimard) through variation acid solution and soaking duration. International Journal of Pharmaceutical Research 2020, 2, 2505-2511.

2. Mrázek, P.; Gál, R.; Mokrejš, P.; Krejčí, O.; Orsavová, J. Thermal stability of prepared chicken feet gelatine gel in comparison with commercial gelatines. Potravinarstvo Slovak Journal of Food Sciences 2020, 14, 535-543, https://doi.org/10.5219/1297.

3. Khirzin, M.H.; Hilmi, M.; Labanasem, K. Study of gelatin from duck bone as an alternative sources of halal gelatin. Jurnal Sains Natural 2020, 10, 1-5. 
4. Tan, C.C.; Karim, A.A.; Uthumporn, U; Ghazali, F.C. Effect of extraction temperature on the physicochemical properties of gelatine from the skin of black tilapia (Oreochromis mossambicus). Journal of Physical Science 2019, 30, 1-12, https://doi.org/10.21315/jps2019.30.s1.1.

5. Ismail, N.; Abdullah, H.Z. The extraction of gelatin from black tilapia fish skins with different acid concentration. Journal of Physics: Conference Series IOP Publishing 2019, 1150, 1-5, https://doi.org/10.1088/1742-6596/1150/1/012041.

6. Zhang, T.; Sun, R.; Ding, M.; Li, L.; Tao, N.; Wang, X.; Zhong, J. Commercial cold-water fish skin gelatin and bovine bone gelatin: Structural, functional, and emulsion stability differences. LWT Food Science and Technology 2020, 125, 1-8, https://doi.org/10.1016/j.lwt.2020.109207.

7. Karayannakidis, P.D.; Zotos, A. Fish processing by-products as a potential source of gelatin: a review. $J$ Aquat Food Prod Technol 2016, 25, 65-92, https://doi.org/10.1080/10498850.2013.827767.

8. Siburian, W.Z.; Rochima, E.; Andriani, Y.; Praseptiangga, D. Fish gelatin (definition, manufacture, analysis of quality characteristics, and application): A review. International Journal of Fisheries and Aquatic Studies 2020 8, 90-95.

9. Lv, L.C.; Huang, Q.Y.; Ding, W.; Xiao, X.H.; Zhang, H.Y.; Xiong, L.X. Fish gelatin: The novel potential applications. Journal of Functional Foods 2019, 63, 1-14, https://doi.org/10.1016/j.jff.2019.103581

10. Rasli, H.I.; Sarbon, N.M. Preparation and physicochemical characterization of fish skin gelatine hydrolysate from shortfin scad (Decapterus macrosoma). International Food Research Journal 2019, 26, 287-294.

11. Ranasinghe, R.A.S.N.; Wijesekara, W.L.I.; Perera, P.R.D.; Senanayake, S.A.; Pathmalal, M.M.; Marapana, R.A.U.J. Functional and bioactive properties of gelatin extracted from aquatic bioresources-a review. Food Reviews International 2020, 16, 1-44, https://doi.org/10.1080/87559129.2020.1747486.

12. Atma, Y. Fish Gelatin Hydrolysates as Antioxidant, Antihypertensive and Antidiabetic: The Plausible Mechanisms. Mini-Reviews in Organic Chemistry 2021, https://doi.org/10.2174/1570193X17666200831180801.

13. da Trindade Alfaro, A.; Balbinot, E.; Weber, C.I.; Tonial, I.B.; Machado-Lunke, A. Fish gelatin: characteristics, functional properties, applications and future potentials. Food Eng Rev 2014, 7, 33-44, https://doi.org/10.1007/s12393-014-9096-5.

14. Mahmoodani, F.; Ardekani, V.S.; See, S.F.; Yusop, S.M.; Babji, A.S. Optimization and physical properties of gelatin extracted from pangasius catfish (Pangasius sutchi) bone. J Food Sci Technol 2014, 51, 31043113, https://doi.org/10.1007/s13197-012-0816-7.

15. Atma, Y.; Ramdhani, H. Gelatin extraction from the indegenous pangasius catfish bone using pineapple liquid waste. Indones J Biotechnol 2017, 22, 86-91, https://doi.org/10.22146/ijbiotech.32472.

16. Chemat, F.; Vian, M.A.; Cravotto, G. Green extraction of natural products: concept and principles. Int J Mol Sci 2012, 13, 8615-8627, https://doi.org/10.3390/ijms13078615.

17. Mohamadpour, F.; Feilizadeh, M. Citric acid as a green and naturally biodegradable catalyst promoted convenient synthesis of polysubstituted dihydro-2-oxypyrrole derivatives via four-condensation reaction of dialkylacetylenedicarboxylate, formaldehyde and amines. Biointerface Research in Applied Chemistry 2019, 9, 4096-4100, https://doi.org/10.33263/BRIAC94.096100.

18. Mariod, A.A.; Fadul, H. Gelatin, source, extraction, and industrial applications. Acta Sci Pol Technol Aliment 2013, 12, 135-147.

19. Karlaganis, G. Citric Acid: SIDS Initial Assessment Report for 11th SIAM. Unep Publication: Berne, Switzerland, 2001; pp. 1-102.

20. Penniston, K.L.; Nakada, S.Y.; Holmes, R.P.; Assimos, D.G. Quantitative assessment of citric acid in lemon juice, lime juice, and commercially-available fruit juice products. J Endourol 2008, 22, 567-570, https://doi.org/10.1089/end.2007.0304.

21. Haleblian, G.E.; Leitao, V.A.; Pierre, S.A.; Robinson, M.R.; Albala, D.M.; Ribeiro, A.A.; Preminger, G.M. Assessment of citrate concentrations in citrus fruit-based juices and beverages: implications for management of hypocitraturic nephrolithiasis. J Endourol 2008, 22, 1359-1366, https://doi.org/10.1089/end.2008.0069.

22. Atma, Y.; Lioe, H.N.; Prangdimurti, E.; Seftiono, H.; Taufik, M.; Fitriani, D.; Mustopa, A.Z. The proportionratio on Dipeptidyl Aminopeptidase-4 (DP-4) inhibition by gelatin compared to synthetic sitagliptin. J Immunoass Immunochem 2019, 40, 386-395, https://doi.org/10.1080/15321819.2019.1613243.

23. Shakila, R.J.; Jeevithan, E.; Varatharajakumar, A.; Jeyasekaran, G.; Sukumar, D. Functional characterization of gelatin extracted from bones of red snapper and grouper in comparison with mammalian gelatin. LWT Food Sci Technol 2012, 48, 30-36, https://doi.org/10.1016/j.lwt.2012.03.007.

24. Atma, Y.; Lioe, H. N.; Prangdimurti, E.; Seftiono, H.; Taufik, M.; Mustopa, A.Z. Dipeptidyl peptidase IV (DPP-IV) inhibitory activity of ultrafiltration and gel filtration fractions of gelatin hydrolysates derived from bone of fish for antidiabetes. Int $J$ Adv Sci Eng Inf Technol 2019, 9, 2096-2103, https://doi.org/10.18517/ijaseit.9.6.10658.

25. Ayudiarti, D.L.; Hastarini, E.; Susilowati, R. Physical characteristics of gelatin from cork fish skin in the waters of merauke. In E3S Web of Conferences EDP Sciences 2020, 147, 1-6, https://doi.org/10.1051/e3sconf/202014703027.

26. Taheri, A.; Abedian Kenari, A.M.; Gildberg, A.; Behnam, S. Extraction and physicochemical characterization of greater lizardfish (Saurida tumbil) skin and bone gelatin. J Food Sci 2009, 74, 160-165. 
27. Atma, Y.; Ramdhani, H.; Mustopa, A.Z.; Pertiwi, M.; Maisarah, R. Karakteristik Fisikokimia Gelatin Tulang Ikan Patin (Pangasius sutchi) Hasil Ekstraksi Menggunakan Limbah Buah Nanas (Ananas comosus). Agritech 2018, 18, 56-63, https://doi.org/10.22146/agritech.29821.

28. Sanaei, A.V.; Mahmoodani, F.; See, S.F.; Yusop, S.M.; Babji, A.S. Optimization of gelatin extraction and physico-chemical properties of catfish (Clarias gariepinus) bone gelatin. Int Food Res J 2013, 20, 423-430.

29. AOAC International. Official Methods of the Association of Official Agricultural Chemist's International. 17th ed.; AOAC Press: Gaithersburg, Maryland, 2005.

30. Uslu, M.E.; Mele, A.; Bayraktar, O. Evaluation of the hemostatic activity of equisetum arvense extract: The role of varying phenolic composition and antioxidant activity due to different extraction conditions. Biointerface Research in Applied Chemistry 2019, 9, 4157-4163, https://doi.org/10.33263/BRIAC94.157163.

31. da Trindade Alfaro, A.; Simões da Costa, C.; Graciano Fonseca, G.; Prentice, C. Effect of extraction parameters on the properties of gelatin from king weakfish (Macrodon ancylodon) bones. Food Sci Technol Int 2009, 15, 553-562, https://doi.org/10.1177/1082013209352921.

32. Pertiwi, M.; Atma, Y.; Mustopa, A. Z.; Maisarah, R. Karakteristik Fisik Dan Kimia Gelatin Dari Tulang Ikan Patin Dengan Pre-Treatment Asam Sitrat. Jurnal Aplikasi Teknologi Pangan 2018, 7, 83-91, https://doi.org/10.17728/jatp.2470.

33. Koli, J.M.; Basu, S.; Nayak, B.B.; Patange, S.B.; Pagarkar, A.U.; Gudipati, V. Functional characteristics of gelatin extracted from skin and bone of Tiger-toothed croaker (Otolithes ruber) and Pinkperch (Nemipterus japonicus). Food Bioprod Process 2012, 90, 555-562, https://doi.org/10.1016/j.fbp.2011.08.001.

34. Keenan, T.R. Gelatin. In: Polymer Science: A Comprehensive Reference. Matyjaszewski, K.; Möller, M., Eds.; Elsevier Science: Oxford, UK, Volume 10, 2012; pp. 237-247.

35. Karim, A.A.; Bhat, R. Fish Gelatin: Properties, challenges, and prospects as an alternative of mammalian gelatins. Food Hydrocoll 2009, 23, 563-576, https://doi.org/10.1016/j.foodhyd.2008.07.002.

36. The Gelatin Manufacturers Institute of America's (GMIA). Standard Testing Methods for Edible Gelatin. Availabe online: http://www.gelatingmia.com/uploads/1/1/8/4/118450438/gmia_official_methods_2019.pdf (accessed on 2 November 2019).

37. Gelatin Manufactures of Europe (GME). Standardised Methods for The Testing of Edible Gelatine. Available

online: https://www.gelatine.org/fileadmin/user_upload/gme_content/GME_Statements/GME_S_Monograph_Sta ndardised_Methods_for_the_Testing_of_Edible_Gelatine.pdf (accessed on 2 November 2019).

38. Nurul, A.G.; Sarbon, N.M. Effects of pH on functional, rheological and structural properties of eel (Monopterus sp.) skin gelatin compared to bovine gelatin. Int Food Res 2015, 22, 572-583.

39. Chandra, M.V.; Shamasundar, B.A. Texture profile analysis and functional properties of gelatin from the skin of three species of fresh water fish. International Journal of Food Properties 2015, 18, 572-584, https://doi.org/10.1080/10942912.2013.845787

40. Fatimah, D.; Jannah, A. Efektivitas penggunaan asam sitrat dalam pembuatan gelatin tulang ikan bandeng (Chanos-Chanos Forskal). Alchemy 2009, 1, 7-15, https://doi.org/10.18860/al.v0i0.1663.

41. Shyni, K.; Hema, G.S.; Ninan, G.; Mathew, S.; Joshy, C.G.; Lakshmanan, P.T. Isolation and characterization of gelatin from the skins of skipjack tuna (Katsuwonus pelamis), dog shark (Scoliodon Sorrakowah), and rohu (Labeo rohita). Food Hydrocoll 2014, 39, 68-76, http://doi.org/10.1016/j.foodhyd.2013.12.008. 